\title{
SOCIETAL REFLECTIONS OF EVOLUTION OF STOVE IN RURAL INDIA
}

\section{SEEMA BANSAL}

Department of Master of Design, National Institute of Fashion Technology, New Delhi, India

\begin{abstract}
This research analyses the effects on the society from the evolution, in design and technical expertise of a cooking stove in rural India, ever since its inception. The objective is to trace simultaneously, the advancement in manual skill and requirements, in order to review the circumstances associated, that lead to the change in design. The combustion of carbons such as firewood, coal, and later hydrocarbons such as oil and gas, accelerated the generation of surplus energy, which in turn contributed to dramatic improvements in the quality of human life. These improvements in design have direct association with the social life of women, in rural India. This paper addresses to the study evolution of cooking stove concluding that, smarter use of energy is the key to higher stages of social evolution.
\end{abstract}

KEYWORDS: Stove, Consumption, Efficiency, Fuel, Technologies \& Product Design

Received: Oct 06, 2017; Accepted: Nov 25, 2017; Published: Dec 20, 2017; Paper Id: IJEEFUSFEB20181

\section{INTRODUCTION}

Designing of things, ideally requires a marriage of human needs with the technology available at that point of time, balanced against various constraints (including the vital one of cost). Therefore, design evolves with time as developments in technology provide new opportunities, for better ways of doing things. Subsequently, human expectations and requirements also change over time.

All living organisms deploy energy in one form or the other, but it is only the human beings, who have developed cumulative surpluses. These surpluses are vital input, for economic and social development, and lead to material "progress" of the societies. This collection of surplus energy was made possible, by the historic transition from food gathering and primitive farming to industrial production, facilitated by the use of various unconventional resources also.

\section{REVIEW OF LITERATURE}

The combustion of carbon i.e. firewood, coal, and later hydrocarbons, such as oil and gas, accelerated the generation of surplus energy, which in turn contributed to the dramatic improvements in the quality of life. However, the way of combusting these resources have implications and complications, effacing on the society as well. In India, $64 \%$ of the population relies on solid fuel for their household cooking needs. Although, a majority of the attempts have been unsuccessful, to improvise the cooking stove in rural India, there have been successful prototypes in disseminating improved cook stoves. Views on adopting cook stoves seem to vary at the user level, and at the project or national level. It was only from starting mid 1980s that, the national administration strategized improved Cooking campaigns. Next to China, India is reported to have the largest number of improved cook stoves installed now. 


\section{HISTORY OF EVOLUTION}

The word 'stove' has been originated from an old English word 'stofa', which means 'any individual enclosed space'. Therefore, a stove is known to be a kitchen appliance, designed for the purpose of cooking food. With the fortuitous accident of the food falling in the fire, came the concept of consuming cooked food.

\section{Open Fire}

In its earliest attestation, cooking was done through open fires (Bellis, 2014). One of the oldest and technologically simplest cooking methods developed by civilization was the first kind of rudimentary stove ever known, the "three stones stove" (Figure.1.) (VITA, 1980) with its perennially archaic status quo of billions of users (Moreshwar, 2014) using firewood for fuel in the pre-industrial era of India. Numerous problems were associated with its usage, the major one being the loss of heat because of lack of enclosure, which resulted in fuel wastage. Another problem with this method was uneven cooking and lack of stability.

Later to cater to this problem, crude enclosures were made out of mud or clay to reduce the heat loss in order make the chulha more efficient (Figure.2). The young girls alone or accompanied by mothers spent hours, walking miles to collect the wood for cooking and drying flat cakes of cow dung in the sun. Their indulgence in these frittering activities affected their schooling and ultimately reflected on their poor education. More than that, this stove had an average efficiency of mere $15 \%$, which meant that $85 \%$ of the effort spent on fuel collection was actually getting wasted (Menon, 2010).
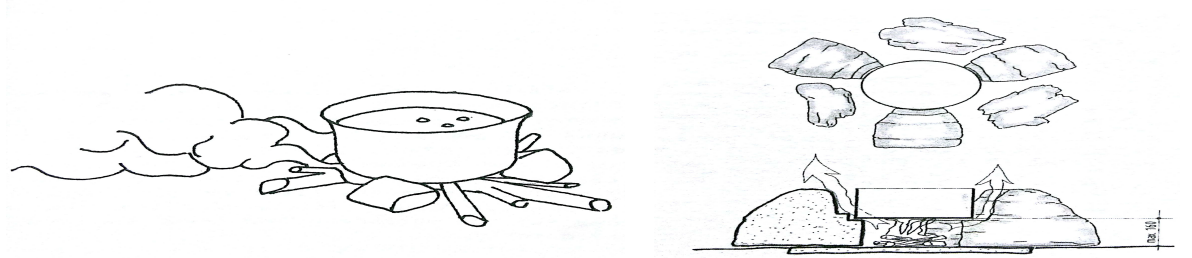

Figure 1: Three Stones Stove (VITA, 1980)

Another pestering problem with the design was that the development of cracks due to repeated heating and cooling (Douglas, 2014), which easily damaged the enclosure. Therefore, it was decided to appoint a village artisan as, 'Chulha-mistri'; the job of this local woman was to rebuild the stove after a regular interval of few months (Nystrom, 1985).

\section{Improved Chulha}

As economic liberalization augmented, general wealth migrated to newly industrializing economy. Gradually small-scale industries were setup, which constructed the enclosures with cement (Figure.3) or with a mixture of cement and clay according to their manual skill. The process of making the enclosure was also intelligent as they were deploying prefabricated moulds. This made them more rigid, stable and resolved the complains of durability. 


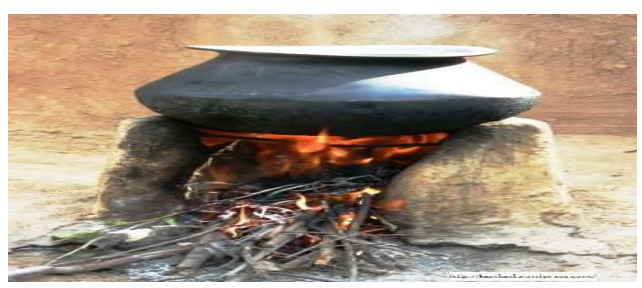

Figure 2: Custom Chulha (Kankad, 2009)

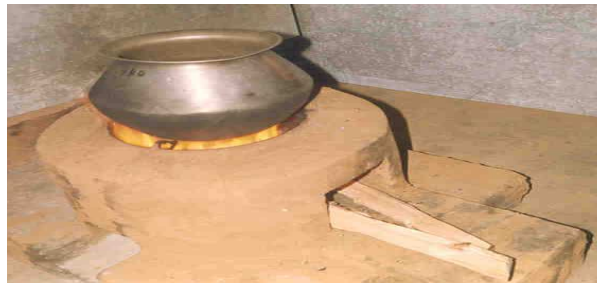

Figure 3: Fabricated Chulha (VITA, 1980)

Almost after every $3 \mathrm{~km}$, a new culture or subculture can be observed in India, because of its wealthy heritage and culture. Thus, one can mark difference in variety of ingredients and the way they are cooked and presented. Considering such diversity in cooking practices, requirement of fuel energy is different, their cooking utensils are different and cooking time varies drastically which needs to be considered before adoption of suitable stove for the people. So one-fit-mouldedmodel-for-all was later replaced. Though it might have solved the major flaws of clay and mud (VITA, 1980) enclosure, but the efficiency was still really low.

In order to resonate with the wave of urbanisation, people started migrating from villages in search of jobs and better opportunities in life. Hence, need of a portable chulha was budding, this lead to Mangan Chulah (Nystrom, 1985) (Figure.4). In Mid 1980's, TATA made series of one-pot metal stoves connected to each other also equipped with small chimney. This brought about another aspect of women's liberalization from household work as the cooking time decreased with increased fuel efficiency. However, wood and other biomass fuel still remained the primary sources of energy for the majority of people.

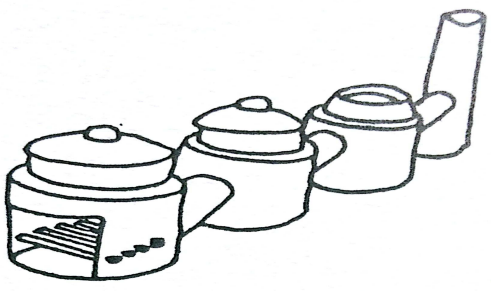

Figure 4: The Mangan Chulha (Nystrom, 1985)

In decades' time, India was experiencing a dual challenge. First being the rise in population and second was the rapid depletion of natural forest resources which resulted in giving ever a harder time for women and young girls who spent a substantial part of their time and energy in search of firewood and often had to cover longer distances. Alongside this phenomenon, deforestation and soil erosion led to many destructive ecological consequences.

Gradually, adverse impacts on human health gained attention. The practice of open fires and traditional stoves led to incomplete combustion of fuel, causing high Black Carbon (BC) emissions. Short-term and long-term exposures to Black Carbon resulted in broad range of respiratory and cardiovascular diseases, eye infections, headache as well as premature deaths. World Health Organisation (WHO) reported 25\% of annual 1.6 million fatalities (Menon, 2010) associated with indoor cooking in India. This brought huge concerns and compelled the government to work towards reduction of smoke. Hence in 1985, the ministry of non-conventional energy sources in India, started a National Program on Improved Chulhas (NPIC) (Khopkar, 2010), to achieve the twin objective of conserving fuel wood and reducing smoke in kitchen. Under this program, 35 million units of smoke reduction chulha design (Figure.5) were installed, with focus on chimneys (Menon, 2010). 
The significance of well ventilated rooms, positioning of the cook stoves in the house, behaviour pattern of women who cooked, the cooking methods and food to be cooked all played crucial role, in designing improved cook stoves. As stove had been an indispensible part of the livelihood, by this time it could be associated as an integral part of the human development.

Though smoke was reduced to $90 \%$ by now (Menon, 2010), women still felt two problems with this design a) it took a lot of time to cook, b) the temperature modulation was absent (VITA, 1980).

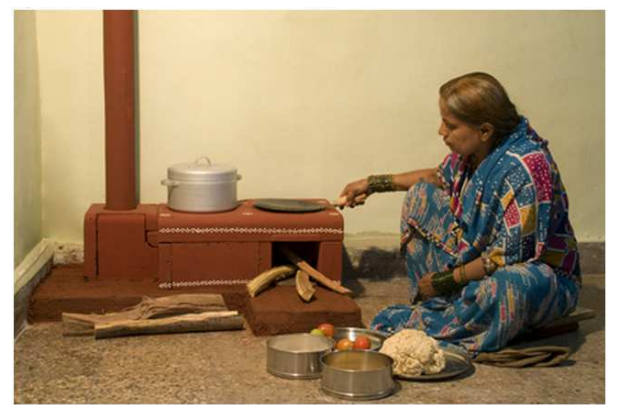

Figure 5: Smoke Reduction Chulha by NPIC (Khopkar, 2010)

\section{Gasified Stove}

There was a major unacknowledged contrast in the effective cost of the energy used in India's rural households and urban domiciliary. In 1991, National Census reported that the most widely used fuel in Indian households was wood (more than 60\%) followed by dung (about 15\%) and small amounts of Kerosene, LPG and coal. The main aim for the improvement of cooking stoves shifted to reduce the heavy burden on local forests for providing firewood for the stoves.

As India was struggling to minimize the causes of pollution, an Alliance-funded research showed that household air pollution was a major contributor to air pollution. By evaluating the impact of household energy consumption on 640 districts across India, researchers found that almost 30\% of the country's outdoor air pollution is due to household energy combustion whereas in some districts, household air pollution contributed up to $50 \%$. This made it very clear that reducing outdoor air pollution required addressing to the air pollution level at the households as well.

By the year 2002, large oil corporations started producing LPG in cylinders. As a result, Ministry of Petroleum and Natural Gas and the Ministry of Finance announced execution of subsidy programs on domestic LPG with effect from 1st August 2002 (Ministry of Petroleum \& Natural gas, 2002). This was a substantial rise in LPG consumption.

Introduction of gas stove (Figure.6) was a revolutionary step forward, as it brought along 360-degree changes in the demographics of cooking. LPG reduced the $\mathrm{CO} 2$ content to about one-fourth to that that of firewood resulting in its huge acceptance. This meant fewer cases of cancer, heart diseases, respiratory tract diseases like asthma etc. It was for the first time that the women could cook while standing without bothering about the hunt of the fuel wood (Nystrom, 1985). In addition to that the cooking pans and pots remained clean from bottom (Douglas, 2014) with usage of LPG. This meant the overall time of cooking reduced. During this period, average LPG consumers grew around 4.4 million per year. In the year 2005 the number of LPG users in India crossed 100 million out of which 30 million were rural households making LPG as one of their most widely used fuel for cooking. 


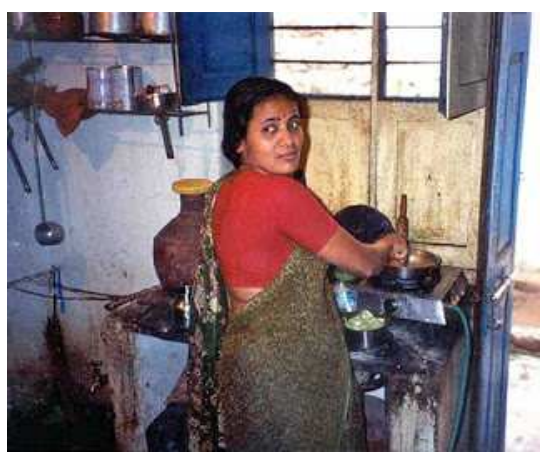

Figure 6: LPG Stove (Douglas, 2014)

The government along with "Community Biogas Project" (Khopkar, 2010), sponsored by Commission for Additional Sources of Energy (Nystrom, 1985) launched "National Biomass Cook stove initiative". The aim of this initiative was to provide alternative energy sources as clean as LPG to the rural India. Keeping the trend of reducing the use of non-renewable fuels in 2014 , Government of India with the help of state government started the state wise projects for solar cooker installation. The program aimed at reducing demand of usage of conventional sources of energy by at least $10 \%$ by the end of five years (Ministry of New and Renewable Energy (MNRE), 2015). A number of other initiatives were taken, to improve the cook stoves were undertaken at the State level, funded by business and international organization. (Aggarwal \& Chandal, 2004)

Soon the kitchen was no longer seen as corner space of one room and was further acknowledged with modularity. An important hallmark of the scheme was governmental development of quality standards, along with exhaustive efforts to recruit entrepreneurs for the manufacture of devices.

\section{CONCLUSIONS}

Still over $60 \%$ of rural households in India depend on firewood or wood chips for cooking. The use of liquefied petroleum gas (LPG) for cooking in rural areas has increased to 15\% of households only during the period $1992-2012$ (Ministry of statistics, 2015). As women are the major users of the stoves, they need to be involved in all stages of development and promoting improved cooking stoves. An awareness drive amongst women by the women can help in horizontal spread of the technology and sensitizing about the health impacts and other benefits of using the new improved stoves.

The current trend is towards manufacturing durable, efficient, less polluting stoves. There are many new designs around the world but the challenge continues to find ways to make these new stoves more affordable and suitable in accordance with the need of today's rural population which still is dependent on centuries-old cooking practices. In this context, it is worth going back to 19th-century social philosophers like Herbert Spencer who saw "energy" not just as a physical variable that described the means to accomplish work but also considered the smarter use of energy as the key to higher stages of social evolution.

\section{REFERENCES}

1. Waclaw, M., 1985. Modern Stoves For All. Revised Edition ed.

2. Nystrom, M., 1985. Kitchen And Stove: The selection of technology and Design.

3. VITA, 1980. Wood Conserving Cook Stoves: A design guide. ITDG Publication. 
4. Anon., 1985. Cookstove News Designing Efficiency into Ovens.

5. Clay, R., 2009. Beautiful Thing: An Introduction To Design. New York: Oxford.

6. Tambini, M., 1996. The Look of the Century. 1st ed. DK Adult.

7. Kumar Singh, V. et al., 2014. Performance Evaluation of Biomass Cooking Devices in Household Environment with Various Solid Biomass Fuel. International Journal of Energy Science, 4(1).

8. Anil Rupnar \& Pushpendra Chauhan, Design, Development of Domestic Cookstove Suitable for Different Solid Biomass Fuel, International Journal of Environment, Ecology, Family and Urban Studies (IJEEFUS), Volume 6, Issue 6, November December 2016, pp. 15-22

9. Wang, Y., 2015. Negotiating Access: A Case Study of Liquefied Petroleum Gas Cookstove Diffusion in India. The Energy Collective.

10. Moreshwar, H., 2014. Future of Cook stoves. Mumbai: TERRE Policy Centre, Pune.

11. Aggarwal, R.K. \& Chandal, S.S., 2004. Review of Improved Cook stoves Programme in Western Himalayan State of India. Elsevier Limited, 27(2).

12. Venkataraman, C., Sagar, A., Habib, G. \& Smith, K., 2010. The Indian National Initiative for Advanced Biomass Cookstoves: The benefits of clean combustion. Energy for Sustainable Development. pp.63-72.

13. Mukunda, H.S., 2010. Gasifier stove-Science, technology and field outreach. Current Science, 98(5).

14. Subramanin, M., 2014. Deadly Diners. Nature, 509, pp.548-51.

15. Samer, A., 2008. Competing for Development: A Case Study of Fuel Efficient Stoves for Darfur. The University of Western Ontario.

16. Rosser, J.B. \& Marina, V.R., 2004. Comparative Economics in Transforming the World Economy. MIT Press. pp., pp.468-70.

17. Chadda, M., 2000. Building Democracy in South Asia. Lynne Rienner Publishers.

18. Lewis, F., 1988. FOREIGN AFFAIRS; Cold War Recedes. New York Times.

19. Hanbar, R.D. \& Karve, P., 2002. National Programme on Improved Chulha (NPIC) of the Government of India: an overview. Elsevier, 6(2), pp.49-55.

20. Douglas, F.B., 2014. From Traditional to modern stoves: A chronology of development. [Online] Available at: "http://www.energyfordevelopment.com/2014/05/from-traditional-to-modern-stoves_25.html" http://www.energyfordevelopment.com/2014/05/from-traditional-to-modern-stoves_25.html [Accessed 13 August 2015].

21. Khopkar, A., 2010. ncsu.edu. [Online] Available at: "https://sites.google.com/a/ncsu.edu/khopkarworldforestry/" https://sites.google.com/a/ncsu.edu/khopkarworldforestry/ [Accessed 15 August 2015].

22. Teri, 2015. Clean combustion cook stove for domestic cooking applications. [Online] Available at: "http://www.teriin.org/technology/stove-writeup" http://www.teriin.org/technology/stove-writeup [Accessed 14 August 2015].

23. Britannia, 2011. From Clay to Steel: A brief history of Cooking Stoves. [Online] Available at:"http://www.britannialiving.co.uk/news/from-clay-to-steel-a-brief-history-of-cooking-stoves" http://www.britannialiving.co.uk/news/from-clay-to-steel-a-brief-history-of-cooking-stoves [Accessed 14 August 2015$].$

24. Shannon, D.L., 2014. The Evolution of Stoves. [Online] Available at: "http://www.builddirect.com/blog/the-evolution-ofstoves/" http://www.builddirect.com/blog/the-evolution-of-stoves/. 
25. Ministry of Petroleum \& Natural gas, 2002. Execution of Subsidy Programmes. [Online] Government of India Available at: "http://petroleum.nic.in/subsidy.htm" http://petroleum.nic.in/subsidy.htm [Accessed 22 August 2015].

26. Ministry of New and Renewable Energy, 2014. National Biogas and Manure Management Programme (NBMMP). [Online] Government of India Available at: "http://mnre.gov.in/schemes/decentralized-systems/schems-2/" http://mnre.gov.in/schemes/decentralized-systems/schems-2/ [Accessed 23 August 2015].

27. Ministry of New and Renewable Energy (MNRE), 2015. MNRE Programme on "Development of Solar Cities". [Online] Government of India Available at: "http://mnre.gov.in/file-manager/UserFiles/solar_city_guidelines.pdf" http://mnre.gov.in/file-manager/UserFiles/solar_city_guidelines.pdf [Accessed 20 August 2015].

28. Menon, M., 2010. Design Resource on Kitchen products. [Online] Available at: "http://www.dsource.in/resource/kitchenproducts/stoves/chulha/index.html" http://www.dsource.in/resource/kitchen-products/stoves/chulha/index.html [Accessed 14 August 2015].

29. Bellis, M., 2014. History of the ovens from cast iron to Electric. [Online] Available at: "http://inventors.about.com/od/ofamousinventions/a/oven.htm" http://inventors.about.com/od/ofamousinventions/a/oven.htm [Accessed 14 August 2015].

30. Indiacurry.com, 2014. What are traditional indoor cooking stoves in India. [Online] Available at: "http://www.indiacurry.com/faqappliance/traditionalstoves.htm" http://www.indiacurry.com/faqappliance/traditionalstoves.htm [Accessed 14 August 2015]. 
